DOI 10.37882/2223-2982.2021.11.02

\title{
МЕТОДИЧЕСКАЯ ПОДДЕРЖКА ВОСПИТАНИЯ В МНОГОДЕТНОЙ СЕМЬЕ
}

\section{METHODOLOGICAL SUPPORT OF UPBRINGING IN A LARGE FAMILY \\ E. Antoshko}

Summary: The purpose of the study is to reveal the concept, the main directions of the content, forms and possible results of the implementation of methodological support for the educational function of a large family as one of the productive activities of specialists who assist parents and members of large families in the competent implementation of the educational function of the family in the interests of improving the quality of life and social stability.

Keywords: methodological support, educational function, large family, counseling, education.
И сследователи и практики нынешнего времени совместно с государством берут на себя большую ответственность содействовать раскрытию и развитию семейного творческого потенциала и семейной культуры, формированию педагогических компетенций и укреплению ресурсности членов семьи в семейном воспитании, способствующему решению актуальных жизненных задач повышения качества жизни и обеспечения социальной устойчивости семьи.

Исследователь М.А. Жигалик, рассматривая актуальные вопросы повышения педагогической компетентности многодетных родителей, раскрывает необходимость обеспечения «доступности компетентной поддержки родителей по вопросам воспитания и развития детей в формах, наиболее удобных для многодетных родителей, позволяющих увеличивать успешность повышения у них педагогической компетентности и способствовать актуализации приоритета семейного воспитания, признавая его уникальность и неповторимость, бесценный воспитательный потенциал» [4].

Целью исследования является раскрытие понятия, основных направлений содержания и форм осуществления методической поддержки воспитательной функции многодетной семьи как одного из продуктивных видов деятельности специалистов, способствующих родителям и членам многодетных семей в грамотном осуществлении воспитательной функции семьи в интересах повышения качества жизни и социальной устойчивости.
Антошко Елена Анатольевна

эксперт-консультант, Карельский региональный общественный благотворительный фонд «Центр развития молодёжных и общественных инициатив» elena.antoshko@mail.ru

Аннотация: В статье на основе теоретического исследования и практического эксперимента, проведённого организациями - партнёрами совместно $\mathrm{C}$ заинтересованными многодетными семьями через систему консультирования и просвещения, раскрываются понятие, основные направления и формы осуществления методической поддержки воспитательной функции многодетной семьи.

Ключевые слова: методическая поддержка, воспитательная функция, многодетная семья, консультирование, просвещение.

\section{Понятийная основа методической подАер»кКи воспитательной функции многодетной семьи.}

Исследование сути понятия методической поддержки, возможные формы и содержание её проявления позволяют выявить оптимальные способы осуществления методической поддержки воспитательной функции многодетной семьи с целью развития её потенциальности и ресурсности как стратегически важного субъекта воспитательных отношений.

Исследование понятийных основ методической поддержки, проявленных педагогами - исследователями подтверждает, что в основном понятие «методическая поддержка» используется с целью раскрытия деятельности методических служб, оказывающих помощь педагогам и специалистам.

Изучение данной проблемы позволило выявить основные формулировки определений методической поддержки, формы её проявления.

Исследовали рассматривают методическую поддержку как «особый вид развивающего взаимодействия» [7], «постоянное разноплановое взаимодействие субъектов поддержки с ее адресатами» [5], «особый вид деятельности внешних по отношению к школам субъектов, создающих комплекс обеспечивающих условий проведения необходимых изменений там, где их реализация силами только педагогического коллектива невозможна» [3], «разные формы методической работы, направленные на достижение поставленной цели», «комплекс взаимос- 
вязанных целенаправленных действий оказания всесторонней помощи педагогу в решении возникающих затруднений; консультации на этапе выбора пути, конструирование и реализация плана» [8], «оперативное и перспективное реагирование старшего воспитателя на запросы и потребности педагогов» [10], «нормы педагогического взаимодействия, комплекс взаимосвязанных целенаправленных действий, процесс применения диалоговых форм профессионального взаимодействия и коммуникации, оказание всесторонней помощи педагогу в решении возникающих затруднений» [6].

Методическая поддержка многодетной семьи может рассматриваться в контексте поддержки педагогической, социально-педагогической, социальной, семейного просвещения и консультирования, которое относится к одному из форм «психолого-педагогической помощи, оказываемой семье, супругам, имеющим несовершеннолетних детей, самим детям разного возраста» и позволяющей решать задачи «осмысления своей деятельности по сохранению нравственного климата в семье, формирования наиболее оптимальных внутрисемейных отношений... проблем взаимоотношения с детьми и их воспитания...»[9].

Подход исследователей к методической поддержке в семейном консультировании и просвещении и отсутствие в научно-педагогической литературе и нормативной правовой базе определения «методическая поддержка семьи» и «методическая поддержка воспитательной функции многодетной семьи» позволяет авторам исследования рассматривать методическую поддержку воспитательной функции многодетной семьи как социально-педагогическую систему выстраивания отношений участников воспитания, обеспечивающую конструктивное и доброжелательное их взаимодействие, учитывающую ожидания и интересы, потребности и способности друг друга, и направленную на содействие в решении актуальных жизненных и воспитательных задач, совместное выявление особенностей, специфики, рисков воспитания в многодетной семье, стремление к гармоничному социокультурному развитию и духовному совершенствованию каждого участника отношений, поиск оптимальных поддерживающих технологий, форм, методов и способов сотрудничества и сотворчества в интересах качества жизни многодетной семьи и её социальной устойчивости.

\section{Основные направления содержания и формы мето ической поццер»кки воспитательной Функции многодетной семьи}

Осуществление методической поддержки многодетной семьи в настоящее время наилучшим образом проявляется в рамках осуществления национального проекта «Образования» и его важного федерального проекта «Современная школа» (ранее - «Поддержка семей, имеющих детей») [2].

Консультирование и просвещение родителей и членов многодетных семей по оказанию поддержки родителям (законным представителям) на федеральном и региональном уровнях позволяют созданным при государственных, муниципальных и социально ориентированных некоммерческих организациях Консультативным центрам оказывать родителям и членам многодетных семей методическую поддержку воспитательной функции по направлениям, сформулированным на основе правовых документов, методических материалов и запросов родителей и членов многодетных семей:

1. Особенности нормативного развития ребенка дошкольного и школьного возраста. Поддержка родителями и специалистами детей разного возраста и индивидуальных особенностей средствами воспитания.

2. Содействие формированию и развитию коммуникативных и социокультурных компетенций ребёнка, преодолению трудностей в общении со сверстниками, членами семьи, взрослыми, братьями и сёстрами разных возрастов при возможном дефиците внимания со стороны родителей.

3. Способствование конструктивному взаимодействию родителей и членов семьи с гиперактивными/ агрессивными/тревожными детьми и профилактика девиантного поведения.

4. Содействие в формировании навыков устойчивого внимания, гибкой памяти и творчески активного и вариативного мышления детей разного возраста, различных способностей к развитию и познанию.

5. Содействие родителям в выстраивании грамотного взаимодействия с детьми в кризисные периоды жизненного роста.

6. Раскрытие потенциала ресурсности семейного воспитания в условиях больших вызовов и неопределённости нынешнего времени, невозможности точного прогнозирования результатов принимаемых решений, непредсказуемости воспитательных рисков.

7. Взаимодействие в семье с ребенком (детьми) с инвалидностью или ограниченными возможностями здоровья.

8. Особенности адаптации ребенка (детей) в приемной семье и специфика реализации приёмными родителями воспитательной функции многодетной семьи.

9. Психолого-педагогическая поддержка многодетными родителями детей разного уровня образования в периоды текущих и итоговых аттестаций, болезни, пандемии и др.

Для учёта особенностей многодетных семей, связан- 
ных с разновозрастностью членов семьи, многоаспектностью домашних забот, профессиональной и образовательной загруженностью, необходимой социальной реализацией методическая поддержка родителей (законных представителей) и членов многодетных семей осуществляется через доступные формы деятельности:

- исследование потребностей, ресурсов, удовлетворённости, готовности к осуществлению воспитательной функции;

- индивидуальное и групповое консультирование;

- открытые творческие встречи и мастерские с семьями;

- проектировочные и обучающие семинары, вебинары, сессии;

- создание и реализация просветительских, культурно-образовательных, психолого-педагогических, музейно-педагогических и др. программ повышения семейного и родительского творческого потенциала, в том числе с использованием информационно-телекоммуникационных Интернет - ресурсов;

- выпуск печатных и электронных информационнометодических материалов;

- участие в фестивалях и конкурсах, раскрывающих творческий потенциал многодетных семей;

- содействие родителям (законным представителям) и членам многодетных семей в проявлении общественного потенциала и участия в деятельности общественных объединений, реализующих программы в интересах детей и семей;

- содействие родителям (законным представителям) и членам многодетных семей в проявлении общественно-государственного потенциала и участия в деятельности органов государственно- общественного управления муниципального, регионального и федерального уровней;

- содействие родителям (законным представителям) и членам многодетных семей в независимой оценке качества условий оказания образовательных услуг детям и семьям;

- содействие родителям (законным представителям) и членам многодетных семей в развитии духовно-нравственного потенциала и социальном служении в общественных и религиозных организациях.

Новые условия жизни меняют содержание, технологии, формы и методы семейного воспитания, взаимодействия семьи с субъектами воспитания, содержание и способы методической поддержки воспитательной функции многодетной семьи.

Президент Российской Федерации в своём послании Федеральному собранию в январе 2020 года призвал всех социальных партнёров семьи в решении «чувствительных» для семьи вопросов: «каждый ... шаг, новый закон, государственную программу ... оценивать, прежде всего, с точки зрения высшего национального приоритета - сбережения и приумножения народа России. Выстраивая долгосрочную политику поддержки семьи, нужно идти от конкретных жизненных ситуаций, разбираться, с какими трудностями сталкивается молодая, многодетная или неполная семья» [1].

Данные ориентиры страны дают многодетной семье надежду на развитие её потенциала жизнеспособности и жизнедеятельности, а организациям, осуществляющим методическую поддержку, уверенность в значимости сотрудничества с многодетными семьями.

\section{ЛИТЕРАТУРА}

1. Послание Президента Российской Федерации Федеральному Собранию, 15.01.2020 // [Электронный ресурс]. URL: http://www.garant.ru/hotlaw/ federal/1314404/ [Дата обращения 20.09.2020]

2. Федеральный проект «Поддержка семей, имеющих детей», Паспорт Национального проекта «0бразование», Президиум Совета при Президенте Российской Федерации по стратегическому развитию и национальным проектам, протокол №16 от 24. 12.2018 // [Электронный ресурс]. URL:

3. http://static.government.ru/media/files/UuG1ErcOWtjfOFCsqdLsLxC80PFDkmBB.pdf [Дата обращения 20.09.2020]

4. Афанасьева Т.П., Копотева Г.Л., Логвинова И.М., Мерзликина И.В., Молодых Е.Н. Методическая поддержка как фактор формирования функциональной грамотности в системе общего образования // Отечественная и зарубежная педагогика. 2020. Т. 2, № 2 (70). — С. 219-235. // [Электронный ресурс]. URL: https://elibrary.ru/download/elibrary_44358184_98751351.pdf [Дата обращения 20.09.2021]

5. Жигалик М.А. Повышение педагогической компетентности многодетных родителей, Вестник Новгородского государственного университета, 2017 № 4 (102). — C.43 - 46 // [Электронный ресурс]. URL: https://cyberleninka.ru/article/n/povyshenie-pedagogicheskoy

6. kompetentnosti-mnogodetnyh-roditeley [Дата обращения 20.09.2021]

7. Моисеев А.М., Моисеева 0.М. Внешняя поддержка новшеств в общеобразовательных организациях // Педагогическое образование и наука. 2013. № 5. C. 50 - 54 // [Электронный ресурc]. URL: https://www.elibrary.ru/item.asp?id=21519879 [Дата обращения 20.09.2021]

8. Методическая деятельность//ГБУ ДПО РО «Ростовский институт повышения квалификации и профессиональной переподготовки работников образования» // [Электронный ресурc]. URL: https://ripkro.ru/deyatelnost/metodsopr/ [Дата обращения 20.09.2021]

9. Пятаева С.А. Методическая поддержка профессионального саморазвития воспитателя дошкольного образовательного учреждения: автореферат дис. 
... кандидата педагогических наук: 13.00.08 / Волгогр. гос. пед. ун-т. - Волгоград, 2005. - 27 с. // [Электронный ресурс]. URL: https://www.dissercat.com/ content/metodicheskaya-podderzhka-professionalnogo-samorazvitiya-vospitatelya-doshkolnogo-obrazovate [Дата обращения 20.09.2021]

10. Сидорова А.В. Методическая поддержка: опыт построения эффективной модели повышения квалификации, Народное образование, 2017, № 6-7. С. 69 - 74 // [Электронный ресурс]. URL:

11. https://cyberleninka.ru/article/n/metodicheskaya-podderzhka-pedagogov-opyt-postroeniya-effektivnoy-modeli-povysheniya-kvalifikatsii/viewer [Дата 06ращения 20.09.2021]

12. Социально-педагогический словарь// М.Н. Бурмистрова и др. Саратовский государственный университет им. Н.Г. Чернышевского, 2016. 一 126 с. C. 49, 75 //[Электронный ресурc]. URL: http://elibrary.sgu.ru/uch_lit/505.pdf) [Дата обращения 20.09.2021]

13. Ткачук Н.Ю. Особенности информационно-методической поддержки педагогов Доу / Н.Ю. Ткачук. — Текст: непосредственный // Аспекты и тенденции педагогической науки: материалы I Междунар. науч. конф. (г. Санкт-Петербург, декабрь 2016 г.). — Санкт-Петербург: Свое издательство, 2016. - С. 82 84. [Электронный ресурс]. // URL: https://moluch.ru/conf/ped/archive/209/11433/ [Дата обращения 20.09.2021]

(c) Антошко Елена Анатольевна (elena.antoshko@mail.ru).

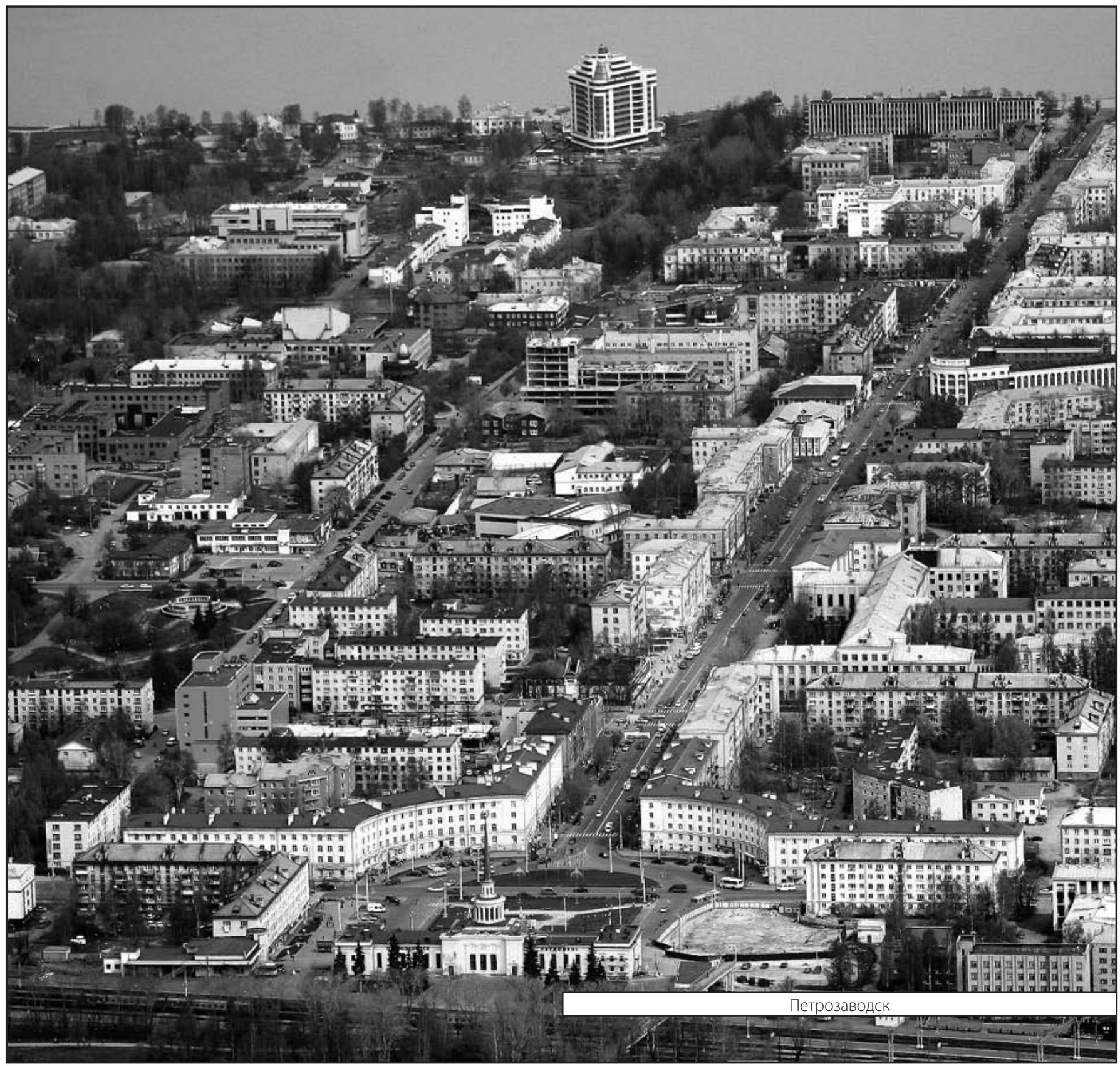

